Original Paper

\title{
Perbandingan Model Pembelajaran Inkuiri Terbimbing dan Inkuiri Bebas Termodifikasi terhadap Hasil Belajar Kimia Siswa ditinjau dari Kemampuan Awal Siswa Kelas X SMAN 1 Masbagik Tahun Pelajaran 2016/2017
}

\author{
Fena Prayunisa $^{1 *}$, Wildan ${ }^{1}$, Harry Soepriyanto ${ }^{1}$ \\ ${ }^{1}$ Program Studi Magister Pendidikan IPA, Pascasarjana Universitas Mataram
}

\author{
*Corresponding Author: \\ Fena Prayunisa, Program \\ Studi Magister Pendidikan \\ IPA, Pascasarjana \\ Universitas Mataram; \\ Email: \\ prayunisa90@gmail.com
}

\begin{abstract}
Penelitian ini bertujuan untuk membandingkan model pembelajaran inkuiri terbimbing dan inkuiri bebas termodifikasi pada pmbelajaran kimia. Model inkuiri bebas termodifikasi adalah gabungan dari inkuiri terbimbing dan inkuiri bebas. Jenis penelitian yang digunakan adalah eksperimen semu (Quasi Experiment) dengan prosedur pelaksanaan menggunakan desain faktorial $2 \times 2$. Masing-masing model pembelajaran disiapkan perangkat pembelajaran berupa silabus, RPP, LKS, dan tes tulis untuk mengukur hasil belajar siswa dan divalidasi ahli terlebih dahulu. Berdasarkan uji validator ahli kedua model pembelajaran mempunyai rata-rata $70 \%$ itu artinya layak untuk digunakan. Sampel yang diambil dalam penelitian ini adalah kelas X IPA-1 menggunakan model inkuiri terbimbing dan X IPA-4 menggunakan inkuiri bebas termodifikasi, dengan nilai semester ganjil sebagai kemampuan awal. Nilai kemampuaan awal yang diatas rata-rata sebagai kemampuan awal tinggi dan di bawah rata-rata sebagai kemampuan awal rendah. Hasil belajar kimia siswa kelas X SMA Negeri 1 Masbagik yang diajarkan dengan pembalajaran inkuiri terbimbing lebih tinggi dibanding siswa yang diajar dengan model inkuiri bebas termodifikasi, ini terlihat dari trata-rata masing kelas yaitu X IPA-1 78.87 sedangkan X IPA-4 73.23. Tidak ada interaksi antara model pembelajaran dengan kemampuan awal terhadap hasil belajar karena kemampuan awal tinggi tidak menjamin nilainya tetap tinggi dan kemampuan awal rendah juga bisa mencapai nilai tinggi.
\end{abstract}

Keywords: Model Inkuiri; Pembelajaran Kimia; Kemampuam Awal.

\section{Pendahuluan}

Pendidikan memiliki peranan yang sangat sentral dalam meningkatkan kualitas sumber daya manusia. Undang-Undang Sistem Pendidikan Nasional (Sisdiknas) no 20 tahun 2003 misalnya, menunjukkan akan peran strategis pendidikan dalam pembentukan SDM yang berkualitas. Karakter manusia Indonesia yang diharapkan menurut undang-undang tersebut adalah manusia yang beriman dan bertaqwa, berbudi pekerti luhur, berkepribadian, maju, cerdas, kreatif, terampil, disiplin, profesional, bertanggung jawab, produktif, serta sehat jasmani dan rohani.

Upaya efektif untuk membentuk karakter manusia seperti ini dapat dilakukan melalui peningkatan kualitas pendidikan. Mengingat peranannya yang sangat penting dalam proses

Publisher

UPT Mataram University Press peningkatan kualitas SDM, maka upaya peningkatan kualitas pembelajaran, khususnya pada mata pelajaran kimia memerlukan perhatian yang serius.

Ilmu kimia adalah suatu mata pelajaran dalam rumpun sains yang dapat mengembangkan kemampuan berpikir analisis dalam menyelesaikan masalah yang berkaitan dengan peristiwa alam sekitar, serta dapat mengembangkan pengetahuan dan keterampilan.

Proses pembelajaran yang hanya ditekankan pada kemampuan untuk menghafal informasi membuat otak siswa dipaksa untuk memahami informasi yang diingatnya itu tanpa menghubungkannya dengan kehidupan sehari-hari. Akibatnya siswa akan kaya dengan teori tetapi sangat miskin dalam aplikasi. Kemampuan siswa dalam merumuskan masalah, membuat hipotesis, 
analisis, dan menyimpulkan masih kurang. Banyak faktor yang menyebabkan lemahnya proses pembelajaran.

Paradigma proses pembelajaran di sekolah saat ini menunjukkan bahwa guru belum optimal dalam proses pembelajaran. Sehingga diperlukan pelaksanaan pembelajaran yang mengacu pada peningkatan kualitas aspek-aspek pembelajaran, seperti penggunaan pendekatan, metode, atau strategi pembelajaran, pengembangan konten atau isi materi ajar dan pelaksanaan asesmen. Pemilihan dan penggunaan pendekatan, metode, atau strategi pembelajaran yang sesuai dimaksudkan untuk terjadinya pembelajaran IPA yang afektif.

Dampak yang paling jelas dari permasalahan di atas adalah hasil belajar siswa yang kurang memuaskan. Berdasarkan observasi yang dilakukan di SMAN 1 Masbagik didapatkan nilai hasil ulangan kimia semester satu dari guru kimia yang masih di bawah KKM yang sudah ditentukan yaitu 70. Menurut Muhibbinsyah (2016) faktor-faktor yang mempengaruhi belajar dapat dibedakan menjadi tiga macam meliputi: a.faktor internal (faktor dari dalam diri siswa) yakni keadaan kondisi jasmani/kondisi jasmani dan rohani siswa, b.faktor eksternal (faktor dari luar siswa) yakni lingkungan disekitar siswa, c.faktor pendekatan belajar (approach to learning) yakni upaya belajar siswa yang meliputi strategi dan metode yang digunakan siswa untuk melakukan kegiatan mempelajari materi-materi pelajaran. Dari pernyataan di atas dapat disimpulkan keberhasilan siswa dalam belajar dapat dipengaruhi dua faktor, yang pertama, dari diri siswa sendiri yaitu kemamapuan berpikir siswa dan gaya belajarnya, yang kedua metode dan media yang digunakan guru dalam belajar.

Meskipun sudah diterapkan kurikulum 2013 di sekolah, tetapi jika pelaksanaannya kurang optimal, maka hasilnya akan kurang maksimal. Pada kurikulum 2013 yang perlu diperhatikan antara lain model pembelajaran yang direkomendasikan. Dalam Kurikulum 2013 model pembelajaran yang dapat digunakan dalam pembelajaran kimia yang diharapkan dapat membangkitkan kreativitas dan keingintahuan siswa yang akhirnya akan meningkatkan prestasi belajar siswa adalah Inquiry Based Learning (model inkuiri), Discovery Learning, dan Pembelajaran Berbasis Proyek (PBL).

Kuhlthau, et.al (2007) menyebutkan bahwa: Guided inquiry is a preparation for lifelong learning, not just preparation for a test. Inkuiri terbimbing merupakan persiapan belajar untuk seumur hidup, bukan hanya persiapan untuk mengikuti ujian. Model Pembelajaran Inkuiri bebas merupakan suatu kegiatan belajar yang memberikan kebebasan siswa untuk menentukan masalah sendiri, mencari konsep merancang eksperimen sampai mencari kesimpulan. Di sini guru hanya sebagai teman belajar apabila diperlukan sebagai tempat bertanya. Pernyataan tersebut sesuai dengan pendapat Martin \& Hansen (2002) yang menyebutkan bahwa: open inquiry, students have the purest opportunities to act like scientists, deriving questions, designing and carrying out investigations, and communicating their results. Inkuiri terbuka, memberi siswa kesempatan yang seluas-luasnya untuk bertindak seperti ilmuwan, membuat rumusan masalah, merancang dan melakukan penyelidikan, dan mengkomunikasikan hasilnya

Berdasarkan uraian di atas, peneliti tertarik untuk melakukan eksprimen pembelajaran dengan membandingkan pengaruh model pembelajaran inkuiri terbimbing dan inkuiri bebas termodifikasi terhadap hasil belajar kimia siswa ditinjau dari kemampuan awal siswa kelas X SMAN 1 Masbagik Tahun Pelajaran 2016/2017.

\section{Metode}

Jenis penelitian ini adalah eksperimen semu (Quasi Experiment) dengan prosedur pelaksanaan menggunakan desain faktorial $2 \times 2$.

Table 1 Rancangan Penelitian Faktorial 2x2

\begin{tabular}{lll}
\hline & \multicolumn{2}{l}{ Model Pembelajaran $(\mathrm{A})$} \\
\cline { 2 - 3 } Kemampuan & Model & Model \\
Awal $(\mathrm{B})$ & Pembelajaran & Pembelajaran \\
& Inkkuiri & Inkkuiri Bebas \\
& Terbimbing $\left(\mathrm{A}_{1}\right)$ & Termodifikasi $\left(\mathrm{A}_{2}\right)$ \\
\hline Tinggi $\left(\mathrm{B}_{1}\right)$ & $\mu \mathrm{A} 1 \mathrm{~B} 1$ & $\mu \mathrm{A} 2 \mathrm{~B} 1$ \\
Rendah $\left(\mathrm{B}_{2}\right)$ & $\mu \mathrm{A} 1 \mathrm{~B} 2$ & $\mu \mathrm{A} 2 \mathrm{~B} 2$ \\
Keseluruhan & $\mu \mathrm{A} 1$ & $\mu \mathrm{A} 2$ \\
\hline
\end{tabular}

Keterangan :

$-\mu \mathrm{A} 1 \mathrm{~B} 1=$ Kelas perlakuan model pembelajran inkuiri terbimbing pada siswa berkemampuan awal tinggi

$-\mu \mathrm{A} 1 \mathrm{~B} 2=$ Kelas perlakuan model pembelajran inkuiri terbimbing pada siswa berkemampuan awal rendah

$-\mu \mathrm{A} 2 \mathrm{~B} 1=$ Kelas perlakuan model 


$$
\begin{aligned}
& \text { pembelajran inkuiri bebas } \\
& \text { termodifikasi pada siswa } \\
& \text { berkemampuan awal tinggi } \\
& -\mu \mathrm{A} 2 \mathrm{~B} 2=\text { Kelas perlakuan model } \\
& \text { pembelajran inkuiri bebas } \\
& \text { termodifikasi pada siswa } \\
& \text { berkemampuan awal rendah }
\end{aligned}
$$

Populasi dalam penelitian ini adalah seluruh kelas XIPA di SMAN 1 Masbagik sebanyak 5 kelas $X$ IPA. Pemilihan sampel dilakukan dengan teknik simple random sampling, dengan cara mengambil 2 sampel kelas secara random, selanjutnya dari 2 kelas sampel, secara random ditentukan kelas yang memperoleh pembelajaran dengan perlakuan model pembelajran inkuiri terbimbing dan kelas yang lain dengan model pembelajaran inkuiri bebas.

Dengan cara tersebut di atas, diperoleh 2 kelas sampel, yaitu Kelas XIPA-1 dan Kelas XIPA4. Selanjutnya dilakukan pengumpulan data nilai raport pada mata pelajaran kimia semester ganjil Tahun 2016 Dari nilai raport tersebut dicari nilai rata-rata kelas sebagai nilai pembatas kelompok atas dan kelompok bawah. Siswa yang memperoleh nilai di atas rata-rata disebut sebagai kelompok siswa dengan kemampuan awal tinggi dan sebaliknya yang memperoleh nilai di bawah nilai rata-rata disebut kelompok siswa dengan kemampuan awal rendah.

Analisis data dilakukan terhadap data hasil belajar yang dikumpulkan dengan menggunakan tes setelah kedua kelompok sampel mendapat perlakukan. Sebelum analisis data untuk menguji hipotisis, terlebih dahulu dilakukan pengujian persyaratan pengujian meliputi normalitas, homogenitas varian data. Selanjutnya dilakukan pengujian hipotesis dengan statistik Anova. Dalam perhitungan pengujian hipotesis, peneliti menggunakan bantuan SPSS.

\section{Hasil dan Pembahasan}

\section{Hasil Uji Ahli}

Uji validasi ahli meliputi semua perangkat pembelajaran yaitu Silabus, Rencana Pelaksanaan Pembelajaran (RPP), Lembar Kerja (LKS) dan soal tes tulis yang masing-masing terbagi menjadi 2 yaitu perangkat pembelajaran inkuiri terbimbing dan inkuiri bebas termodifikasi. Validasi dilakukan oleh 3 (tiga) ahli yang memiliki kompetensi di bidang pendidikan dan sains dan diperoleh persentase dari hasil uji validasi terhadap perangkat pembelajaran $70 \%$. Jadi perangkat pembelajaran layak digunakan.

\section{Pengujian Hipotesis}

Hasil belajar kimia siswa kelas X SMA Negeri 1 Masbagik yang diajarkan dengan pembalajaran inkuiri terbimbing lebih tinggi dibanding siswa yang diajar dengan model inkuiri bebas termodifikasi dapat dilihat dari grafik pada Gambar 1:

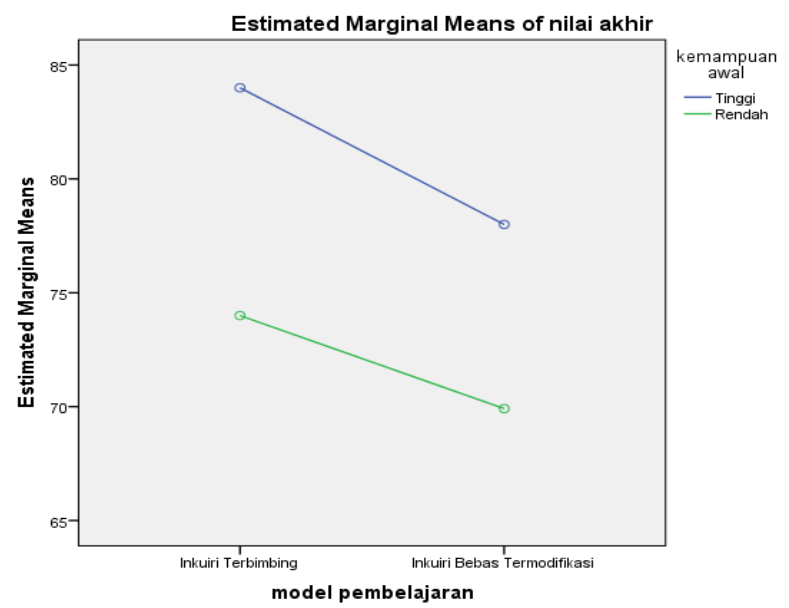

Gambar 1: Grafik Hasil Belajar Kimia Siswa Kelas X SMA Negeri 1 Masbagik yang diajarkan dengan pembalajaran inkuiri terbimbing

Hasil belajar kimia siswa kelas X SMA Negeri 1 Masbagik yang mempunyai kemampuan awal tinggi yang diajarkan dengan pembalajaran inkuiri terbimbing lebih tinggi dibanding siswa yang diajar dengan model inkuiri bebas termodifikasi dapat dilihat dari grafik pada Gambar 2.

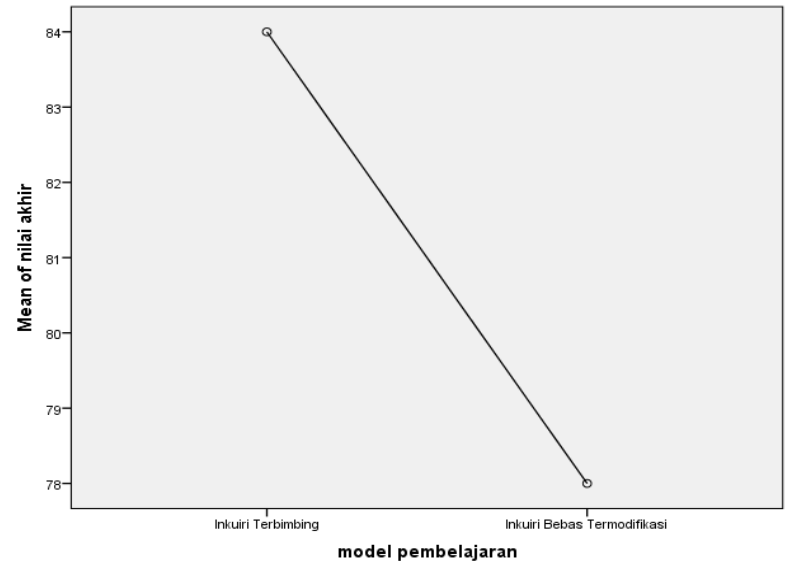

Gambar 2: Grafik Hasil Belajar Kimia Siswa Kelas X SMA Negeri 1 Masbagik yang diajarkan dengan pembalajaran inkuiri terbimbing 
Dari uraian hasil tersebut dilihat perbedaan tahapan dari kedua kelas, kelas yang dibimbing dari awal akan lebih efektif belajar dibandingkan dengan kelas yang diberi kebebasan, karena guru mengawasi secara intens dan dapat memberikan penjelasan di tengah-tengah pembelajaran berlangsung. Siswa juga lebih disiplin saat pembelajaran berlangsung karena merasa diawasi. Sedangkan inkuiri bebas termodifikasi guru memberikan kebebasan seluas-luasnya dalam pengambilan data tanpa dibimbing, jadi selama proses pembelajaran ada yang terkadang bingung apa yang harus mereka lakukan meskipun di dalam LKS sudah ada petunjuk dengan jelas. Tetapi meskipun kurang efektif kelas inkuiri bebas termodifikasi juga dalam penelitian ini dapat meningkatakan hasil belajar karena ini juga tergantung dari faktor siswa itu sendiri dan lingkungan kelas. Lingkungan yang diciptakan oleh inkuiri dalam kelompoknya saling mengenal kemampuan masing-masing, siswa saling menghargai dan saling bekerja sama dalam mencari tahu jawaban yang benar. Siswa belajar sambil menemukan sendiri berdasarkan masalah disekitarnya, dan membuat siswa memiliki pengalaman lebih bermakna dan lebih melekat dalam fikiran mereka.

Denagn kuatnya informasi yang melekat dalam fikiran mereka akan dapat berfikir positif terhadap hasil belajar siswa. Rata-rata seluruh siswa baik kelas inkuiri terbimbing dan inkuiri bebas termodifikasi aktif dalam kegiatan belajar karena siswa harus berfikir dengan keras dan menggunakan kemampuannya dengan maksimal. Selain itu, dalam penerapannya model inkuiri terbimbing memberikan kesempatan kepada siswa untuk memecahkan masalah yang telah disampaikan sebelumnya oleh guru melalui gambar, peragaan, atau situasi yang sesungguhnya, dan untuk mengalami sendiri dalam mengikuti proses, bahkan siswa dituntut menganalisis, membuktikan, dan menarik kesimpulan sendiri mengenai suatu objek, sehingga siswa termotivasi untuk lebih belajar percaya diri dan berimbas pada hasil belajar siswa yang semakin mening-kat. Sedangkan pada metode inkuiri bebas termodifikasi, guru memberkan suatu permasalahan dan siswa berusaha dituntut untuk meme-cahkan masalah tersebut dengan cara melakukan kegiatan ilmiah seperti menganalisis data dan menarik kesimpulan. Pada metode inkuiri bebas termodifikasi pemecaha masa-lah dilakukan siswa atas inisiatif dan caranya sendiri. Guru hanya berperan sebagai fasilitator dan sedikit membimbing siwa dengan memberikan pertanyaanpertanyaan yang sifatnya mengarahkan siswa pada pemecahan masalah. Dengan teknik tersebut pada saat proses pembelajaran, belum cukup untuk membuat siswa memahami dan membentuk pengertian dengan baik, sehingga hasil belajar yang diperoleh siswa dengan menggunakan metode inkuiri bebas termodifikasi belum dapat mengungguli hasil belajar dengan pembelajaran yang menggunakan metode inkuiri terbimbing.

Hasil belajar kimia siswa kelas X SMA Negeri 1 Masbagik yang mempunyai kemampuan awal rendah yang diajarkan dengan pembalajaran inkuiri terbimbing lebih tinggi dibanding siswa yang diajar dengan model inkuiri bebas dapat dilihat dari grafik pada Gambar 3:

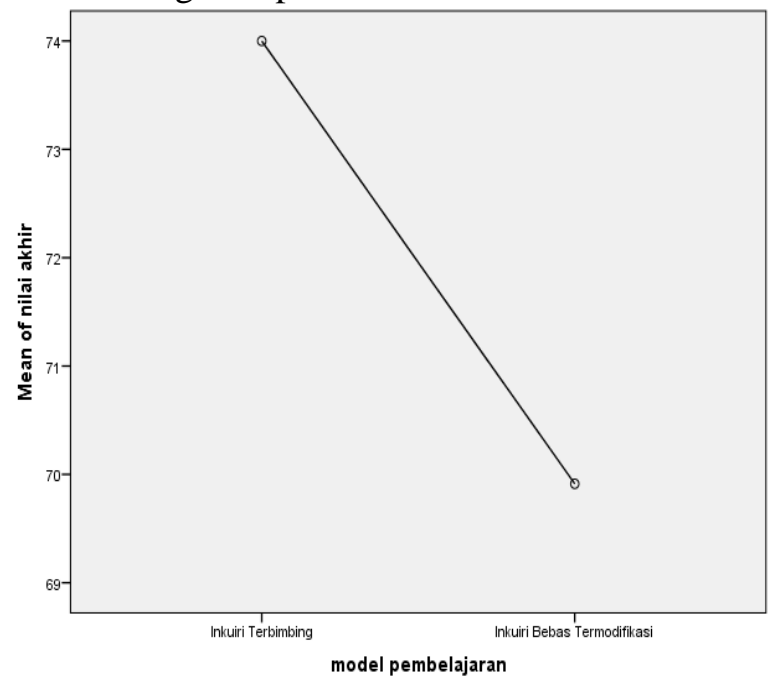

Gambar 3: Hasil belajar kimia siswa kelas X SMA Negeri 1 Masbagik

Hasil belajar kimia siswa kelas X SMA Negeri 1 Masbagik yang diajarkan dengan pembalajaran inkuiri terbimbing lebih tinggi dibanding siswa.

Dari uraian di atas dapat dilihat perbedaan tahapan dari kedua kelas, kelas yang dibimbing dari awal akan lebih efektif belajar dibandingkan dengan kelas yang diberi kebebasan, karena guru mengawasi secara intens dan dapat memberikan penjelasan di tengah-tengah pembelajaran berlangsung. Siswa juga lebih disiplin saat pembelajaran berlangsung karena merasa diawasi. Tetapi meskipun kurang efektif kelas inkuiri bebas juga dalam penelitian ini dapat meningkatakan hasil belajar karena ini juga tergantung dari faktor siswa 
itu sendiri dan lingkungan kelas. Siswa yang memiliiki kemampuam di atas rata-rata, artinya siswa yang memiliki kemampuan belajar bagus tidak akan terhambat oleh siswa yang lemah dalam belajar. Siswa dengan kemampuan awal tinggi memiliki keinginan yang kuat untuk mempelajari sesuatu yang masih baru atau belum diketahui, serta senantiasa mengikuti pembelajaran dengan sungguh-sungguh. Tetapi dalam model pembelajran inkuiri bebas termodifikasi siswa belum terbiasa di "lepas" dalam arti bimbingan yang lebih sedikit daripada inkuiri terbimbing, meskipun konsep dari model pembelajaran ini adalah menemukan sendiri tetapi siswa juga perlu bimbingan dalam langkahlangkah pembelajaran.

Sejalan dengan penelitian Hadiati, (2011: 145) siswa yang memiliki kemampuan awal yang baik jika tidak mengikuti kegiatan pembelajaran inkuri dengan baik tentu saja tidak mendapatkan peningkatan hasil belajar. Bisa jadi karena siswa yang dibelajarkan dengan inkuiri bebas termodifikasi tidak mengikuti pembelajaran dengan baik, menyebabkan nilainya lebih rendah daripada yang dibelajarkan menggunakan model inkuiri terbimbing. Hal ini kemungkinan karena faktor belum terbiasanya melaksanakan pembelajaran sendiri dengan sangat sedikit bimbingan dari guru.

\section{Kesimpulan}

Berdasarkan penerapan model pembelajaran inkuiri terbimbing dan dan inkuiri bebas termodifikasi terhadap kemampuan hasil belajar siswa pada pelajaran kimia dalam penelitian maka dapat disimpulkan bahwa:

1. Penerapan model pembelajaran inkuiri terbimbing dan inkuiri bebas termodifikasi berpengaruh positif terhadap hasil belajar siswa pada pelajaran kimia baik kelas eksperimen dan kelas kontrol.

2. Penerapan model pembelajaran inkuiri terbimbing dan inkuiri bebas termodifikasi berpengaruh positif terhadap hasil belajar siswa yang berkemampuan awal tinggi. Meskipun hasil belajar inkuiri terbimbing lebih tinggi daripada inkuiri bebas termodifikasi, tetapi kedua model dapat meningkatkan hasil belajar siswa.

3. Penerapam model pembelajaran inkuiri terbimbing dan inkkuiri bebas termodifikasi tidak berpengaruh terhadap hasil belajar siswa yang memiliki kemampuan awal rendah. Tetapi model dan kemampuan awal berdiri sendiri. Terjadi peningkatan hasil belajar karena itu dari faktor siswa sendiri.

\section{Daftar Pustaka}

Hadiati, S. 2011. Pembelajaran Fisika dengan Metode Inkuiri Terbimbing dan Inkuiri Bebas Termodifikasi ditinjau Dari Kemampuan Awal dan Sikap Ilmiah. Surakarta: Universitas Surakarta

Kuhlthau, C. C., Maniotes, L.K., \& Caspari, A.K. 2007. Guided Inquiry Learning in The $21^{S T}$ Century. London, Libraries Unlimited.

Martin, L. \& Hansen. 2002. Defining Inquiry: Exploring the many types of inquiry in the science classroom. The Science Teacher, February 2002.

Muhibbinsyah. 2016. Psikologi Pendidikan Dengan Pendekatan Baru. Bandung: PT Remaja Rosdakarya. 